
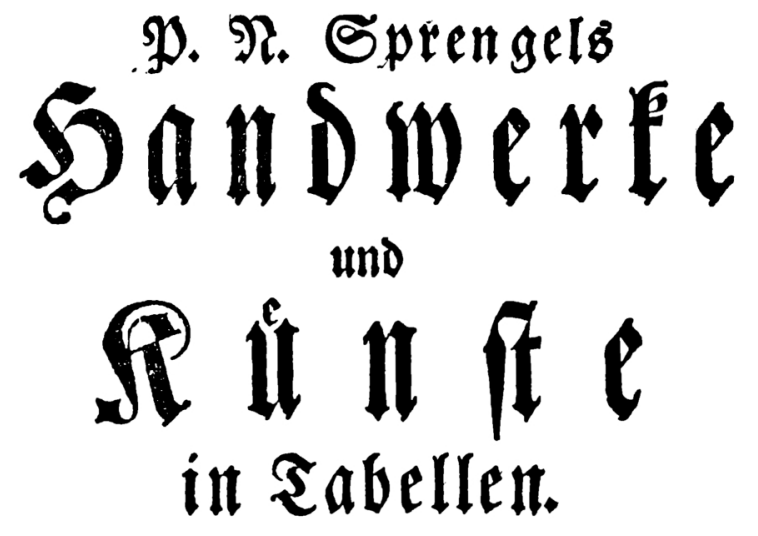

Mit Rupfert.

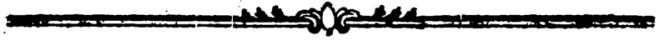

$$
\underset{\text { von }}{\mathfrak{y} \text { orgert }}
$$

D. 2. Saltwig.

\title{
Funfzelnte Sammlung.
}

\section{Berlin,}

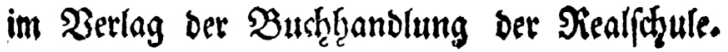

$$
377 \text {. }
$$


